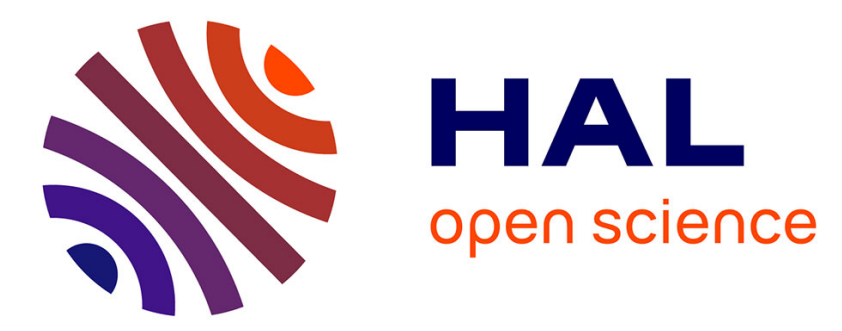

\title{
Incentives and policies for integrated pest management in Europe: a review
}

Marianne Lefebvre, Stephen R. H. Langrell, Sergio Gomez-Y-Paloma

\section{To cite this version:}

Marianne Lefebvre, Stephen R. H. Langrell, Sergio Gomez-Y-Paloma. Incentives and policies for integrated pest management in Europe: a review. Agronomy for Sustainable Development, 2015, 35 (1), pp.27-45. 10.1007/s13593-014-0237-2 . hal-01284266

\section{HAL Id: hal-01284266 https://hal.science/hal-01284266}

Submitted on 7 Mar 2016

HAL is a multi-disciplinary open access archive for the deposit and dissemination of scientific research documents, whether they are published or not. The documents may come from teaching and research institutions in France or abroad, or from public or private research centers.
L'archive ouverte pluridisciplinaire HAL, est destinée au dépôt et à la diffusion de documents scientifiques de niveau recherche, publiés ou non, émanant des établissements d'enseignement et de recherche français ou étrangers, des laboratoires publics ou privés. 


\title{
Incentives and policies for integrated pest management in Europe: a review
}

\author{
Marianne Lefebvre • Stephen R. H. Langrell • \\ Sergio Gomez-y-Paloma
}

Accepted: 24 June 2014 / Published online: 27 August 2014

(C) INRA and Springer-Verlag France 2014

\begin{abstract}
Integrated pest management and organic farming are alternatives for sustainable agriculture and less pesticide use in the European Union. All professional users of pesticides in the European Union should follow the general principles of integrated pest management from 2014. States should report to the European Commission on their national action plan for the effective application of those general principles through crop-specific guidelines. The major remaining issues are: (1) when guidelines are not already applied, what incentives would encourage European farmers to adopt those guidelines? (2) How and to what extent should public money be used to promote the adoption of guidelines? Here, we review the adoption of integrated pest management in Europe. We deliver a framework to understand the drivers of changes in farmers' pest management practices. This framework also helps to understand farmer reaction to different policy incentives.
\end{abstract}

Keywords Integrated pest management · Adoption . Incentives $\cdot$ Sustainable use directive $\cdot$ Pesticides $\cdot$ Sustainable agriculture $\cdot$ Common agricultural policy

\section{Contents}

1. Introduction . . . . . . . . . . . . . . . . . 1

2. Private incentives for integrated pest management adoption . . . . . . . . . . . 3

The views expressed are purely those of the authors and may not in any circumstances be regarded as stating an official position of the European Commission.

M. Lefebvre $(\bowtie) \cdot$ S. R. H. Langrell · S. Gomez-y-Paloma European Commission, Joint Research Centre (JRC), Institute for Prospective Technological Studies (IPTS), Agrilife Unit, Edificio Expo. c/Inca Garcilaso, 3, 41092 Seville, Spain e-mail: marianne.lefebvre@ec.europa.eu
2.1 Cost effectiveness of integrated pest management technology . . . . . . . . . . . . 3

2.2 Market access and price premium with integrated pest management ................ 5

2.3 The role of farmers' attitudes . . . . . . . . . . . . . .99

3. Public policies to foster integrated pest management adoption . . . . . . . . . . . . . . . . . . 10

3.1 Why is public intervention necessary in crop protection? . . . . . . . . . . . 10

3.1.1 Crop protection and externalities . . ........... 10

3.1.2 Crop protection, landscape ecology and coordination failure ............................11

3.2 How can public policies encourage IPM adoption? . 11

3.2.1 Regulatory instruments . . . . . . . . . . . . . 11

3.2.2 Information dissemination measures . . . . . . . . . 12

3.2.3 Incentive-based instruments . . . . . . . . . . . . . 13

3.2 .4 Tax on pesticide use . . . . . . . . . . . . . . . 14

3.2.5 Payments for IPM adoption . . . . . . . . . . . . . . 14

4. Conclusion ............................ 16

References............................. 17

\section{Introduction}

Health and environmental concerns about the risks posed by the use of pesticides have led the European Union to introduce a series of measures in 2009 commonly referred to as the "pesticides package", consisting of four pieces of legislation related to pesticides use. ${ }^{1}$ Within this package, the Sustainable Use of pesticides Directive provides a framework for action to promote the adoption of low pesticide input pest management

\footnotetext{
${ }^{1}$ Regulation (EC) No 1107/2009 concerning the placing of plant protection products in the market, Directive 2009/128/EC establishing a framework for Community action to achieve the sustainable use of pesticides, Regulation (EC) No 1185/2009 concerning statistics on pesticides, Directive 2009/127/EC amending Directive 2006/42/EC with regard to machinery for pesticide application.
} 
approaches, in particular integrated pest management (IPM) (EU 2009a). IPM, as described in the Sustainable Use Directive, is defined as a system based on three main principles: (i) the use and integration of measures that discourage the development of populations of harmful organisms (prevention); (ii) the careful consideration of all available plant protection methods; and (iii) their use to levels that are economically and ecologically justified (Figs. 1 and 2).

Since the introduction of the concept in 1959, many studies have suggested that adoption of IPM principles provides environmental, economic and health benefits (Stern et al. 1959). Despite the various benefits expected from IPM, not all utilized agricultural areas in Europe ${ }^{2}$ are cultivated according to IPM principles. Overall, whilst adoption of IPM is rather common in orchards and protected (greenhouse) production systems, it still remains largely marginal in arable and field crops. But according to the new European legislation (EU 2009b), all professional users of pesticides should follow the general principles of IPM (already since 1 January 2014). European Member States have been asked to set up National Action Plans to support this objective. Notwithstanding, this legislative pressure, an immediate switch cannot be reasonably expected in the highly diverse crop production systems in Europe. During this transition phase, it is unclear how readily such integrated pest management approaches and crop-specific strategies will be adopted, especially whilst knowledge and technology gaps still exist. Moreover, there is high heterogeneity in the National Action Plans and level of commitments of the Member States.

In this context, understanding drivers of change, and how rapidly a switch in the crop protection paradigm from conventional dependent to an IPM basis can be pragmatically achieved is of interest. Why would European farmers adopt such principles if there were no mandatory regulation? Even in the presence of readily workable IPM alternatives, why would farmers adopt them if they are most costly? In the event of higher production costs, will consumers be willing to pay higher prices for goods produced with such approaches? Would retailers be willing to create specific market segments for IPM products? Will insurers be willing to cover the potential risks linked to IPM adoption? Beyond mandatory approaches, to what extent should public money be used to promote IPM adoption? In the de facto interim, how should incentive-based policies be designed? Answers to these questions are beyond the scope of agro-ecology research in pest management, but are nevertheless central to the success of evolution of farming towards the sustainable use of pesticides. Here, the economics tool box can help address some of these questions.

This article draws on a large body of research in economics of pest control and management and provides a reflection on a

\footnotetext{
${ }^{2}$ The terms Europe and European Union are used indistinctly in the text.
}

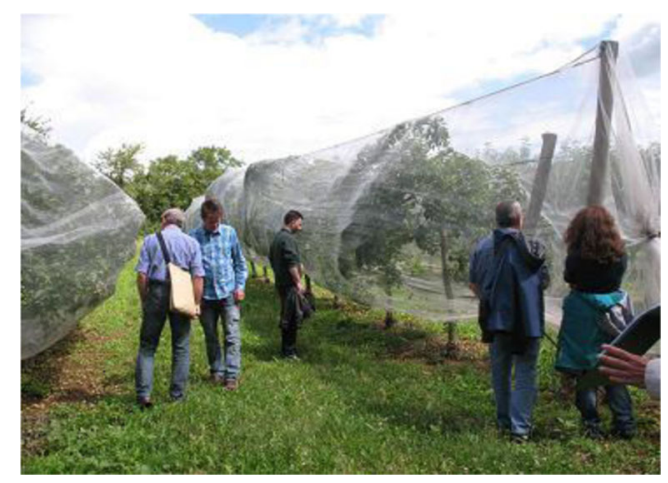

Fig. 1 Alt'Carpo net for pomefruits in Valence (France) (Photo: INRA Gotheron)

range of pertinent issues towards understanding the drivers of change in plant protection practices. A few authors have reviewed the existing research in economics of pest management and pesticide policies (Carlson and Wetzstein 1993; Sexton et al. 2007; Waterfield and Zilberman 2012). However, understanding the drivers of IPM adoption requires another step since IPM covers a large set of principles and is, by far, not solely limited to reducing pesticide use. Such exercises have already been performed in the US, where the US congress has supported IPM development, providing financial backing for large IPM programs since the seventies (McCarl 1981; Kogan 1998; Swinton and Day 2003). Consequently, most of the literature addressing the question of why some farmers adopt IPM, whilst others do not, predominantly concern US farmers, or, in particular, those in developing countries, where low input agriculture is the norm (FernandezCornejo 1996, 1998; Yong-gong and Guo-jun 2001; Mauceri et al. 2005; Sexton et al. 2007; Bonabana-Wabbi et al. 2012). By contrast, with the exception of few specific sectors (e.g. protected crops and fruit production), evidence for the extent and drivers of IPM principles adoption by European farmers remains incomplete (Bailey et al. 2009; Freier and Boller 2009; Sharma et al. 2009; Hillocks and Cooper 2012). In this

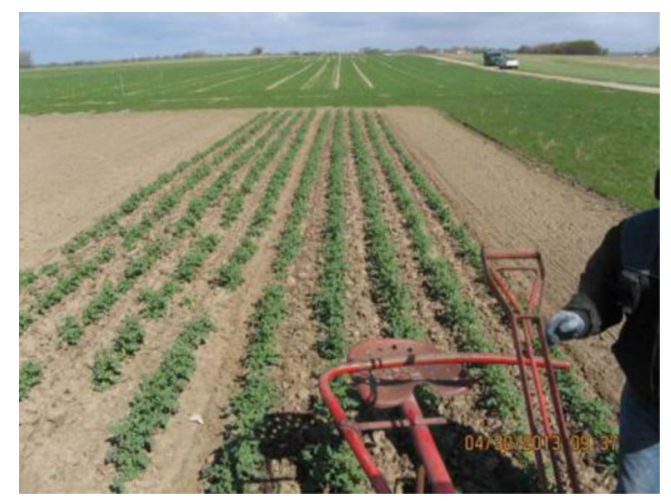

Fig. 2 Inter-row hoeing of winter oilseed rape, as part of an innovative Integrated Pest Management (IPM) solution for winter-wheat based rotations in Flakkebjerg (Denmark) (Photo: PURE) 
article, we propose updated information as well as a selection of questions and literature relevant for the European context.

The target audience of this paper are the extension services and persons in charge of the design or local implementation of measures to support IPM adoption in the European Union, as well as farmers willing to understand the legislation behind the changes in their environment. The objective of the article is to contribute to the understanding of the factors underlying and directing farmer's adoption of new plant protection practices in general, and IPM in particular. This is certainly a prerequisite to predict farmers' expected reactions to different policy incentives, and the successful formulation of policies and extension services supporting the evolution of IPM adoption in the European Union. The article is structured in two sections. In Section 2, we explore private incentives likely to incite IPM adoption. In Section 3, we consider a possible rationale for government intervention, whilst simultaneously illustrating some of the practical challenges in the design and implementation of policies supporting the adoption of IPMbased farming. Based on the review of these two aspects, we conclude in Section 4 with the presentation of an analytical framework to understand the drivers of changes in farmers' pest management practices (Fig. 3).

\section{Private incentives for integrated pest management adoption}

In modern agricultural systems responding to market signals, private incentives are important drivers for the adoption of new technologies and practices. The profitability of a new technology for a given farmer is determined by the characteristics of the production technology itself (its impact on quantity, quality and costs), but also by a number of farm-specific factors, such as farm size, human capital, labour availability, financial constraints, access to information, new inputs and, importantly, markets (Feder et al. 1985; Goodhue et al. 2010). Here, we are interested in those factors likely to encourage European farmers to adopt IPM principles in the absence of mandatory regulation and specific policy instruments. They can be classified into three categories: cost-effectiveness of IPM technology(ies), opportunities offered to IPM products in the market, and other non-financial and behavioural factors. Knowledge of such private incentives is important since it determines the need for, and type of public policies required, which are aspects developed in Section 3.

\subsection{Cost-effectiveness of integrated pest management technology}

Overall, there is a lack of quantitative evidence on the potential of integrated pest management to increase economic sustainability relative to non-IPM strategies under region- and crop-specific growing conditions. Indeed, data on the economic costs and benefits of IPM solutions are scarce, and even more so with consideration of the European context. Moreover, because integrated pest management encompasses many principles and practices, as illustrated by the long list of general principles of IPM in the Annex III of the Sustainable Use Directive (EU 2009c), assessing the cost-effectiveness of

Fig. 3 Incentives for integrated pest management adoptiongeneral framework

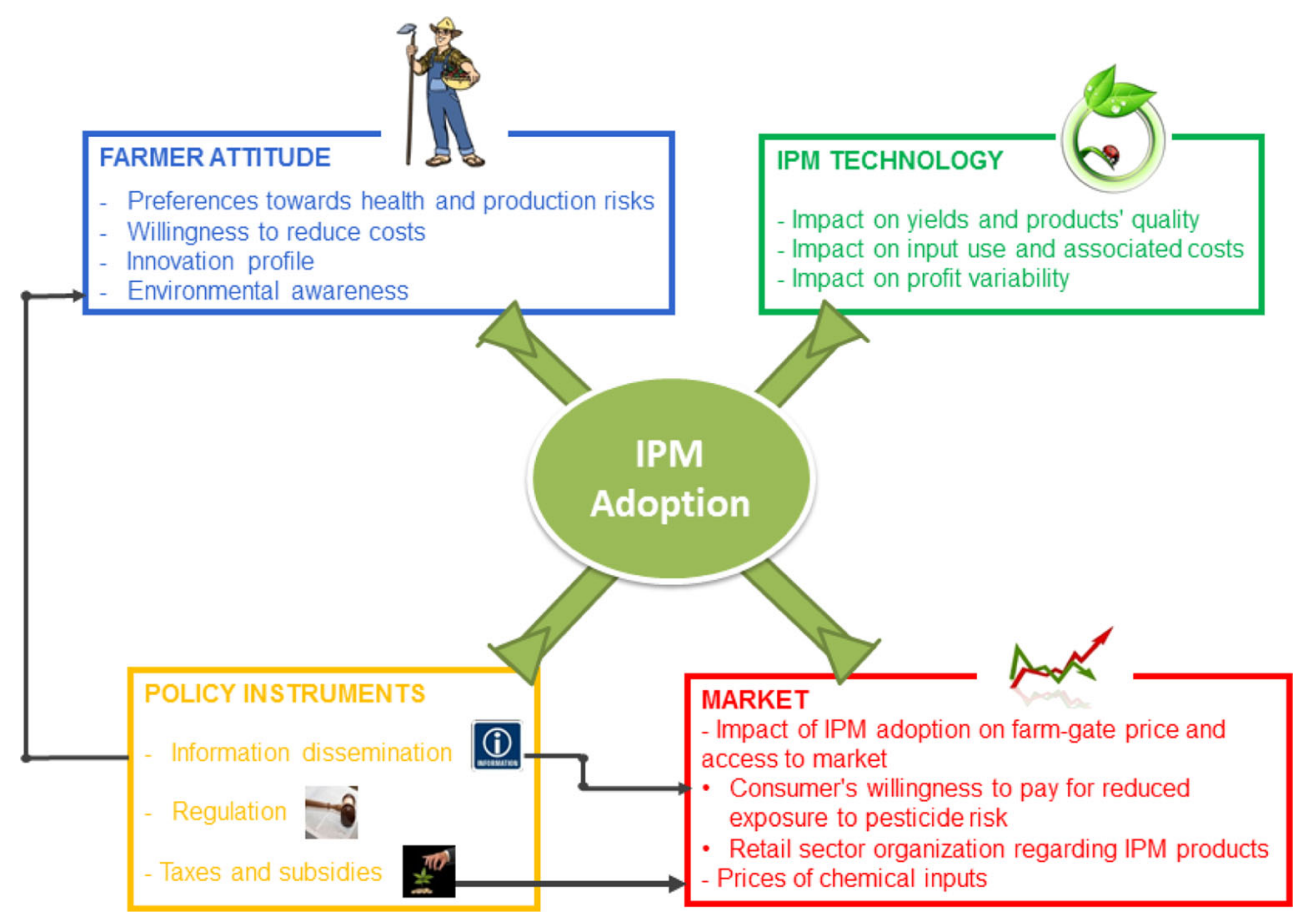


IPM and comparing its implementation across countries is challenging (Waterfield and Zilberman 2012). Moreover, producers often only adopt parts of the spectrum of IPM principles and practices suggested by research and extension services. There is high diversity of "IPM-based" practices, ranging from "almost no IPM" to "ultimate IPM". Furthermore, IPM is a dynamic and continuous process, where the different strategies that are part of IPM are very rarely simultaneously implemented. The assessment of the profitability of partial, or step-wise adoption, is rendered difficult by the fact that the efficiency of pest control is often obtained as a result of the complementarities of the different components within the IPM portfolio or spectrum (Zepeda et al. 2006).

The most comprehensive summary of producer-level economic evaluations of IPM programs to date was developed in the USA (Norton and Mullen 1994; Fernandez-Cornejo 1998). Although evidence in Europe is growing, albeit slowly, it is currently mostly restricted to ex ante analysis based on expert judgment, and rarely on quantitative empirical evidence collected directly from field trials. The on-going PURE project financed by the European Commission FP7 programme (Innovative Crop Protection for Sustainable Agriculture, www.pure-ipm.eu) aims, amongst other objectives, to produce this evidence with on-station and on-farm data, from six key European farming systems (winter-wheat-based rotations, maize-based cropping systems, field vegetable crops, pomefruit, grapevine and protected vegetables) through the evaluation of a range of candidate IPM solutions from intermediate (solutions easy to implement and scientifically validated) to advanced (solutions in the experimental stage). We here provide a summary of recent experience and data in Europe, although limited, on the cost-effectiveness of IPM adoption.

Pelzer et al. (2012) proposed a multi-attribute model (DEXiPM) to perform ex ante assessments of the sustainability of IPM in arable cropping systems, defined in a maize production context corresponding to the French region of Poitou-Charentes. This model highlighted differences between winter crop-based and maize crop-based systems. For the winter crop-based innovative system, economic sustainability was found to decrease for the IPM approach compared to the conventional baseline. Higher labour costs, due to superficial tillage and crop monitoring, were recorded. However, systematic field observations for the monitoring of pests, weeds and disease populations, and treatment decisions based on thresholds defined according to local conditions, can help limit pesticide use to the actual minimal required dosage level, and therefore reduce input costs. Moreover, lower yields and lower selling prices were observed, due to reduced opportunity for alternative cash crops in the rotation. By comparison, for the maize-based system, the economic sustainability was found to be improved with IPM. The production costs are reduced with IPM compare to conventional (lower pesticide, fertiliser and irrigation costs), the yields are higher, but the selling price at the cropping system scale is lower due to the introduction of sunflower in the IPM crop sequence. Other results on ex ante evaluation of more innovative IPM strategies for maize-based cropping systems have also been collected by Vasileiadis et al. (2011). Interviewing experts (mostly advisors) in five European regions (Denmark, Netherlands, Hungary, Spain and Italy), found that automatic weed monitoring, as well as longer-term system monitoring, are expected to have a neutral economic impact. However, deployment of reliable cultivars, pest and disease forecasting models, early detection methods, precision spraying employing advanced Global Positioning System, as well as community-based decisions and information sharing, are all approaches that can result in a system net profit within a time frame of 3-4 years.

Focusing on another top fruit production system, Mouron et al. (2012) proposed a comprehensive methodology (SustainOS) for evaluating the environmental and economic sustainability of region-specific IPM strategies in apple orchards from across 5 European regions (Switzerland, Germany, The Netherlands, France and Spain). Experts estimate that pesticide use can be reduced without reducing total yield or quality, but with considerable differences between countries. In some countries, IPM strategies were expected to increase total yield by up to $29 \%$, and to increase the percentage of first class fruit by up to $20 \%$ compare to conventional strategies. But the use of IPM was predicted to result in economic disadvantages in some countries because some alternative measures are labour and capital intensive. The cost for alternative crop protection measures (such as a higher proportion of area with hail netting or enclosure netting) can be greater than the capital saved by reduced spraying. Furthermore, monitoring and training increase labour costs. Nevertheless, overall, in some of the regions and systems tested, higher yields compensated for increased costs.

Overall, the impact of IPM on cost depends not only on the impact of the adoption of IPM principles on pesticide use, but also on the cost of substitutes. Based on two different samples of French farms producing arable crops (in the departments of Meuse and Eure et Loire), Boussemart et al. (2012) showed that agricultural practices using less pesticide per hectare are cheaper than practices using more pesticides, without increasing the costs due to the use of substitutes. In addition, they found cost dominance ${ }^{3}$ to be a robust phenomenon across size and scope dimensions (Boussemart et al. 2011, 2012). Concerning substitution of chemical control with biological

\footnotetext{
${ }^{3}$ Cost dominance of agricultural practices using less pesticide per ha means that the optimal cost frontier of the farms with lower pesticide use is below the one of farms with higher pesticide use (for farms within the same region with homogenous pedoclimatic characteristics). The cost frontier framework allows for eventual presence of technical and allocative inefficiencies in the data, and is therefore preferred to a traditional cost function.
} 
control, through their review of various studies, Bale et al. (2008) concluded that the cost-benefit ratio for biological control is highly favourable compared to chemical control. Similarly, McConnachie et al. (2003) reviewed several examples of successful applications of biocontrol, with high benefit-cost ratios. Again, such results are highly crop-dependent. Biological control is very well developed and highly profitable in protected environments for greenhouse crops, as well as in many orchards, offering solutions that work technically better than chemical control. In these systems, chemical control often failed because the most important pests had become resistant against the available pesticides. However, it is more difficult to make biological control work in open fields and production systems with short crop cycle.

Quantitative evidence on the impact of the adoption of IPM principles on labour and management costs also remains limited. It is generally agreed that IPM strategies are time and information/knowledge intensive, compared to purely chemical control and more capital-intensive pesticide-based pest management strategy as used in conventional agriculture (Beckmann and Wesseler 2003; Waterfield and Zilberman 2012). Empirical studies in the USA have shown a significant negative impact of off-farm income on the adoption of IPM, confirming that opportunity cost of labour ${ }^{4}$ is an important variable towards explaining rates of adoption. The higher the opportunity cost of labour, the less the farmer is likely to spend time on his farm, and therefore to engage in farming practices labour-intensive (McNamara et al. 1991; FernandezCornejo et al. 1994; Fernandez-Cornejo 1998). Based on survey data from durian growers in Thailand, Beckmann et al. (2009) found that farms employing hired labour exhibited a lower adoption rate of IPM. In other words, the comparative advantage of IPM is higher under owneroperated pesticide application as hired labour is difficult to employ in many IPM tasks. Of course, the validity of this result in Europe will depend on the farm structure considered, as well as the qualification of farmers/agricultural operators.

The evaluation of the economic return of IPM adoption should not be limited to costs and yields effects. Indeed, crop protection also aims at maintaining output quality. It is recognised on one hand that pest damage can reduce the value of agricultural commodities when blemished (Yue et al. 2009), and, on the other, that chemical pesticides can have a qualityimproving effect, especially for fruits and vegetables (Babcock et al. 1992). There is nevertheless evidence that IPM has no negative impact on output quality, measured for

\footnotetext{
$\overline{{ }^{4}}$ The opportunity cost of labour is the best wage the farmer could get in a job outside farming.
}

example as the percentage of first-class fruits (Mouron et al. 2012).

Moreover, the evaluation of the economic return should not be restricted to one growing season. Indeed, benefits from IPM adoption can be delayed in time. For example, relying on the full portfolio of tools at the farmer's disposal —including biological control using natural predators of pests, mechanical control using specific tilling and cultivation techniques, as well as chemical control with pesticides, herbicides, and fungicides - and the systematic alternation between methods can help delay, or even prevent pesticide resistance build-up. This will be a source of cost saving, but only in the long run.

We have summarized here recent studies in Europe on the cost-effectiveness of IPM adoption. Available evidence accounts for the impacts on labour and input costs, as well as on yields, but is often restricted to the evaluation of single strategies part of IPM toolbox, with little guidance on the impact of their integration, the differentiation of the impact in the short and long run, and the potential variability in the results according to crops and agro-climatic conditions. Quantitative evidence on the cost-effectiveness of IPM in Europe is unfortunately too scarce to provide farmers with tools to predict the impact on their profits of IPM adoption. Apart from cost saving, one potential source of economic return consists in establishing new opportunities to sell IPM products compared to conventional products. In the next sub-section, we review the situation regarding the placement and recognition of IPM in the food market.

\subsection{Market access and price premium with integrated pest} management

In general, differentiation of agricultural products, and its communication to the consumer, can provide growers with access to new markets, and, in some cases, price premiums for their product. However, the case of IPM is particular. Here, we review the situation regarding the placement and recognition of IPM in the food market nowadays, and how it is likely to evolve with IPM becoming a mandatory requirement for all agricultural products.

There is evidence that consumers are willing to pay more for reduced exposure to pesticide risk in general (Florax et al. 2005) and for organic products in particular (Torjusen et al. 2004). However, it remains unclear whether products complying with other certifications (e.g. integrated pest management) are recognised and positively valued by consumers. A limited number of studies have focused for example on the willingness to pay for non-organic apples, but certified by schemes including requirements in terms of crop protection (Loureiro et al. 2001; Marette et al. 2012; Bazoche et al. 2013). All these studies concluded that consumers' 
willingness to pay for such certified, but non-organic apples, is significantly higher than consumers' willingness to pay for conventional, and significantly lower than consumers' willingness to pay for organic apples. Although restricted to apples, ${ }^{5}$ these results suggest that IPM products can satisfy a niche market for consumers less willing to trade-off price for higher environmental benefits compared with organic consumers. However, the price premium observed in these experiments, compared with conventional products, is rather low.

Beyond the fact that consumers are only moderately willing to pay more for IPM products, marketing integrated pest management products is not an easy task, in the absence of official label at the European level. First, pest control based on economic thresholds and decision models, without a clear commitment regarding the reduction in overall pesticides use, appears difficult to communicate. Moreover, given the varieties of principles covered by the term "IPM", there is a risk of multiplication of labels, with quite different interpretations and approaches. Not least, such a situation may add to the possible market saturation of certification schemes and labels and information overload for end-consumers. Indeed, in this context, producers are encouraged to apply to different certifications for the same product in order to have access to different market segments (Canali 2011), resulting in increased production costs whilst simultaneously contributing to consumer confusion.

These different arguments may explain why retailers have been reluctant to create a specific market segment for IPM. Currently, in Europe, products grown using IPM are rarely identified as such in the market place for the endconsumers. However, retailers use IPM as a prerequisite for producers to deliver products to market segments with stricter environmental specification or access preferred supplier categories (i.e. the group of suppliers supermarkets will preferentially call upon) (ENDURE 2010). Complying with these general principles of integrated pest management can lead producers to sell at higher prices but not always (Canali 2011). This is explicitly stated in the Global GAP business-to-business certification: "Most people confuse global gap with higher prices, that is, they think that once you have been certified you can charge higher prices than the one who hasn't been. That is not very true. Yes, global gap opens up many markets for you, but it is not an assurance for higher prices. In most European countries, certain products are not allowed unless they are certified. So the benefits of global gap are more markets than more money. But then again if you push more products, you will enjoy economies of scale and make more profits" (http:// www1.globalgap.org).

\footnotetext{
$\overline{5}$ Apples market is often analysed because it corresponds to an important market share of fruit sales and because apple production relies heavily on pesticides.
}

Global GAP is one of these business-to-business certifications integrating some principles of integrated pest management as a requirement. The "Inventory of certified schemes for agricultural products and foodstuffs marketed in the European Union Member States" is the most up-to-date inventory of certified schemes for agricultural products and foodstuffs marketed in European Union Member States (Areté Consultants 2010). Of the 427 certified schemes identified in this inventory, 56 voluntary schemes relate to integrated crop and integrated pest management principles, including both business-to-business and business-to-consumer schemes. They have been developed by the private sector, including both retailers and producers organizations. Fruits and vegetables are by far the crops mostly concerned by IPM certification. As a way of illustration, some of these various schemes are highlighted in Table 1.

With the new European legislation (mandatory compliance with the general principles of integrated pest management for all professional users of plant protection products) certification schemes need to evolve beyond general IPM practices, since, at least in Europe, voluntary certification schemes cannot certify practices corresponding to legal requirements (EC 2010). Therefore, even if the question has already been debated, there will be no official European official for IPM, contrary to what exists for organic farming. Indeed, producer and retailer organizations willing to develop IPM voluntary certification schemes will have to include specific requirements, going further and beyond general IPM principles as defined in the Sustainable Use Directive (certifying the application of more innovative and crop-specific IPM approaches and practices).

Another, not unrelated but associated, question relates to the expected impact of the new legislation on prices and consumers' preferences. As mentioned, IPM has been, up until now, a requirement for market access imposed by retailers. Even if IPM adoption is akin to product differentiation, producers receive no price premium for IPM products. In Europe, adoption of IPM general principles is now a legal requirement imposed by the legislator (and no longer by retailers), but the expected impact is similar, i.e. no price premium for IPM grown products. According to basic economic theory, prices would increase only if largescale adoption would result in higher production costs and lower yields at European level; or by a change in consumers' preferences. Using economic experiments, Biguzzi et al. (2014) found that the gradual reduction of shelf space for conventional tomatoes, following the implementation of the sustainable use directive, would equally benefit organic and IPM tomatoes, whatever the prices. However, in their experimental study, they found that if conventional tomatoes totally disappeared, the winning market segment between organic and IPM would depend on the price difference between these products. 
Table 1 Examples of schemes certifying integrated pest management in the European Union

\begin{tabular}{|c|c|c|}
\hline Name of the scheme & Coverage & How is Integrated Pest Management included? \\
\hline & $\begin{array}{l}\text { EU, extended to } \\
\text { non-EUROPEAN } \\
\text { UNIONcountries } \\
\text { Business to } \\
\text { Business (not } \\
\text { directly visible for } \\
\text { the consumers) }\end{array}$ & $\begin{array}{l}\text { GlobalGAP is a private sector body that sets } \\
\text { voluntary standards for the certification of } \\
\text { agricultural products based on Good Agricultural } \\
\text { Practices (GAP). It was initiated in } 1997 \text { by a } \\
\text { number of retailers represented in the Euro- } \\
\text { Retailer Produce Working Group. It is a pre-farm- } \\
\text { gate-standard that means the certificate covers } \\
\text { the process of the certified product from before } \\
\text { the seed is planted until it leaves the farm. } \\
\text { The Global GAP crops module coversIntegrated } \\
\text { Pest Management, as well as traceability, } \\
\text { propagation material, site history and site } \\
\text { management, soil management, fertilizer } \\
\text { application, irrigation/fertigation, plant protection } \\
\text { products and equipment. } \\
\text { The GLOBAL G.A.P. Database registers the } \\
\text { assessment and ce rtification data of more than } \\
130,000 \text { farms in over } 120 \text { countries. }\end{array}$ \\
\hline 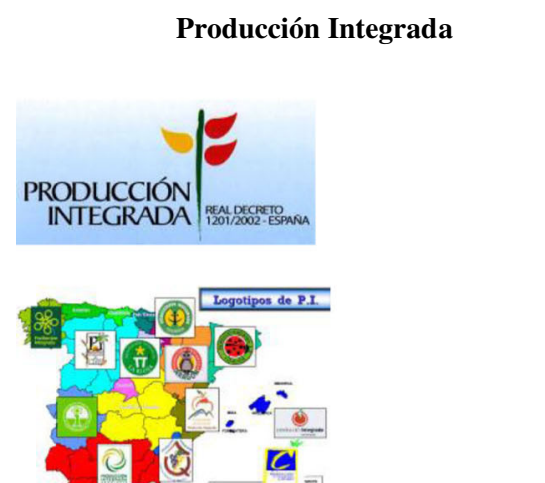 & $\begin{array}{l}\text { Spain } \\
\text { Business to } \\
\text { Consumer }\end{array}$ & $\begin{array}{l}\text { Each Spanish region has developed his own } \\
\text { scheme for integrated production, but since } 2002 \text {, } \\
\text { all regional schemes are covered by the "Real } \\
\text { Decreto } 1201 / 2002 \text {, de } 20 \text { de noviembre, por el } \\
\text { que se regula la producción integrada de } \\
\text { productos agrícolas." Integrated Pest } \\
\text { Managementp rinciples are included in the "crop } \\
\text { protection" chapter of "producción integrada". } \\
\text { Integrated Production certified fa rms can receive } \\
\text { agri-environmental payments. } \\
\text { The surface registered account for } 659294 \text { ha in } \\
2010 \text {. }\end{array}$ \\
\hline $\begin{array}{l}\begin{array}{c}\text { Certification environnementale des } \\
\text { exploitations agricoles }\end{array} \\
\text { La certification } \\
\text { environnementale } \\
\text { des exploitations agniooles }\end{array}$ & $\begin{array}{l}\text { France } \\
\text { Business } \\
\text { Consumer }\end{array}$ & $\begin{array}{l}\text { The French scheme of farms environmental } \\
\text { certification was created in 2010. It is built around } \\
\text { four themes: Biodiversity, Plant protection } \\
\text { strategy, Management of fertilizer use, Water } \\
\text { management. Farms can be certificated at three } \\
\text { different levels: } \\
\text {-Level One: fulfilment of the environmental } \\
\text { requirements in cross -compliance. } \\
\text {-Level Two:compliance with a set of } 16 \text { different } \\
\text { criteria, among which some are related to crop } \\
\text { protection. Among the indicators, some can } \\
\text { reflect a certain level of Integrated Pest } \\
\text { Management( eg. treatment frequency index, use } \\
\text { of non-chemical alternatives to crop protection). } \\
\text { Existing programs have received recognition on } \\
\text { their equivalence with level } 2 \text { (eg. "Agriculture } \\
\text { raisonnée" managed by the inter -professional } \\
\text { association FARRE) }\end{array}$ \\
\hline
\end{tabular}


Table 1 (continued)

\begin{tabular}{|c|c|c|}
\hline Name of the scheme & Coverage & How is Integrated Pest Management included? \\
\hline & & $\begin{array}{l}\text { Level Three "High Environmental Value": It } \\
\text { involves a formal agreement to achieve defined } \\
\text { outcomes. The farmer can choose to be assessed } \\
\text { according to four composite indicators related to } \\
\text { biodiversity, plant protection strategy, fertilizer } \\
\text { use, water management or two synthetic } \\
\text { indicators (share of ecological focus area or } \\
\text { permanent pasture in UAA and share of input } \\
\text { costs in turnover). }\end{array}$ \\
\hline $\begin{array}{c}\text { LEAF } \\
\text { LENE Linking Environment } \\
\text { And Farming }\end{array}$ & $\begin{array}{l}\text { United Kingdom + } \\
40 \text { other } \\
\text { countries in } \\
\text { Europe, Middle } \\
\text { East, South } \\
\text { America and } \\
\text { North Africa } \\
\text { Business to } \\
\text { Consumer }\end{array}$ & $\begin{array}{l}\text { LEAF (Linking Environment And Farming) is a non- } \\
\text { governmental initiative set up in } 1991 \text { with a view } \\
\text { to develop Integrated Farming Management } \\
\text { (IFM). Integrated Pest Management is an integral } \\
\text { part of IFM. Farmers applying for LEAF } \\
\text { certification must first have globalGap } \\
\text { certification, plus extra control points on crop } \\
\text { protection. } \\
\text { In } 2012,357761 \text { ha were LEAF certified across the } \\
\text { world, with } 223141 \text { ha in UK ( } 487 \text { farms). }\end{array}$ \\
\hline Fruitnet & $\begin{array}{l}\text { Belgium, } \\
\text { extended to } \\
\text { Belgique, France, } \\
\text { Spain, New- } \\
\text { Zealand and } \\
\text { South Africa } \\
\text { Business to } \\
\text { Consumer }\end{array}$ & $\begin{array}{l}\text { Fruitnet is an example of private brand who has } \\
\text { designed his own certification scheme, following } \\
\text { the principles described in Belgian law on } \\
\text { integrated production in fruit production (Arrêté } \\
\text { du Gouvernement flamand du } 26 \text { mars 2004). }\end{array}$ \\
\hline IP SUISSE & $\begin{array}{l}\text { Switzerland } \\
\text { Business to } \\
\text { Consumer }\end{array}$ & $\begin{array}{l}\text { IPSuisse is a swiss certification scheme focused on } \\
\text { Integrated Production. It includes three layers: } \\
\text { general requirements for the farm (including legal } \\
\text { requirements and requirements of the program } \\
\text { "Proof of Ecological Performance that sets } \\
\text { minimum standards for direct payments), general } \\
\text { requirements for biodiversity, security and } \\
\text { training, as well as and product-specific } \\
\text { requirements for } 6 \text { categories of products } \\
\text { (cereals, colza, potatoes, fruits, cider and meat). } \\
\text { For the biodiversity requirements, farmers get } \\
\text { points when following some practices (eg. crop } \\
\text { rotation, soil cover, limited fertilizer use, } \\
\text { mechanical weeding, use of auxiliaries, ecological } \\
\text { focus area...) and they need a minimum of points } \\
\text { to be certified. } \\
\text { In } 2014 \text {, } 20000 \text { farms are certified: } 15250 \\
\text { livestock farms, } 4500 \text { cereal producers ( } 24000 \mathrm{ha} \text { ), } \\
250 \text { seed rape producers (950ha). }\end{array}$ \\
\hline
\end{tabular}

Authors own elaboration. We have selected some schemes (non-exhaustive selection) from the list of certification schemes included in the "Inventory of certified schemes for agricultural products and foodstuffs marketed in the European Union Member States" (Areté Consultants 2010). The information presented here is based on information collected on the websites of the different schemes 
In this section, we have analysed the impact of IPM adoption on market access and price premium. In general, IPM products emerge as poorly recognised by the end-consumer, given the relatively few IPM labels on the supermarket shelves. Most certification schemes are business-to-business, where adoption of IPM practices is a requirement for market access. In this context, it is considered that the new legislation will not have a major impact on the market, only force producer and retailer organizations to redefine their certification schemes so that they include requirements that go beyond the legal ones. Finally, it is worth mentioning that the evidence presented in Sections 2.1 and 2.2 concerns merely the impact of IPM adoption on costs, yields and output prices and market access. As such, all these indicators concern the economic dimension. Recent advances in behavioural studies of farmers' decision making warns us against the exclusive use of pure economic rationality frameworks, supporting the inclusion of social, cognitive, as well as emotional factors towards the analysis of production decisions. In the next section, with this in mind, we look at the effect of attitudes on IPM adoption.

\subsection{The role of farmers' attitudes}

Behavioural factors and farmers' attitudes towards risk, innovation or the environment are likely to explain the deviation from an adoption decision purely driven by economic rationality. Such factors are important to take into account as they can impact farmers' responsiveness to policy instruments based on purely financial incentives.

First, we focus on the role of farmers' risk preferences. Pest and disease attacks constitute one of the biggest sources of risk in agriculture; especially because they are likely to provoke "catastrophic risk" (up to $100 \%$ crop losses). Not only can pests and diseases reduce yields, but they can also impact quality, therefore exposing producers to quality-based price risk. Consequently, risk is considered a major factor reducing the rate of adoption of new agricultural technologies (Marra et al. 2003). According to the conventional view, pesticides have been considered an important component in reducing the risk of yield loss and are commonly used as an insurance by risk-averse farmers (Mumford and Norton 1984). However, some results suggest that fertiliser and pesticides may, in fact, constitute risk-increasing inputs in some contexts (Pannell 1991; Horowitz and Lichtenberg 1993; Regev et al. 1997). Quantitative evidence on the impacts of the adoption of IPM principles on production risk are now old references and restricted to the US experience, and they have shown heterogenous results (Musser et al. 1981; Hurd 1994). Currently, and to the best of our knowledge, the only available information in the Europe is given in Mouron et al. (2012), according to whom experts judge income variability (both due to the standard deviation of yield per hectare and the standard deviation of the proportion of first class fruit) to be higher in IPM than in conventional European apple orchards.

In spite of the absence of convincing evidence that profit variability is significantly affected by IPM principles adoption, growers often perceive new practices as posing inherent risk (Musser et al. 1986). In this context, adoption of IPM can be clearly considered as risky, due to the novelty of some of the strategies part of the IPM toolbox, but also the knowledge or experience gap. Farmers can perceive as risky the decision to learn new plant protection methods, compared to the perceived certainties and experiences of the conventional production paradigm and the risk management potential offered by chemical control.

In this context, insurance represents a potential tool to encourage adoption of IPM principles (Feinerman et al. 1992; Mitchell 1999). Until now, there is a relatively low and slow uptake of crop insurance in Europe (compare to the US). Most insurance schemes do not appear well suited to alternative farming practices. For example, the insured party should prove that he has used all possible crop protection tools available in agriculture in order to be compensated for crop losses. Not using maximal chemical control and departing from conventional crop protection tactics could be qualified by insurers as a motive to refuse compensation. Recently, efforts have been made to take into account the specific insurance needs of organic farming. In this respect, the US Agricultural Risk Protection Act now takes into account organic farming specificities (Singerman et al. 2011; USDA 2013). Recently, some private insurance companies have started offering specific insurance policies for organic agriculture in Europe (e.g. "Atout 5 bio" by Crédit Agricole, France). Therefore, conceptually, there is no real impediment as to why this could not be expanded to integrated pest management. Insurance products designed for corn rootworm IPM users have been already developed under a collaboration between the US Department of Agriculture's Risk Management Agency and the Agricultural Conservation Innovation Center (Cubie 1999). However, to date, we are not aware of any similar large-scale experience in the European Union, neither for IPM nor for integrated farming in general.

Beyond farmers' attitudes towards risk, there is evidence that attitudes towards health and environmental risk due to pesticide exposure can be key factors in adoption (Lichtenberg and Zimmerman 1999; Cuyno et al. 2001). Indeed, there is evidence that some farmers are willing to trade-off economic profitability for reduced health and environmental risk due to their farming practices. This would be in favour of IPM since IPM principles contribute to the reduction of environmental risks associated with pesticide use by encouraging the adoption of more ecologically benign control approaches and strategies. Several studies show that the environmental sustainability (as measured by indicators of resource use, water and soil quality, flora and fauna, $\mathrm{CO}_{2}$ emission, etc.) of IPM is 
improved compared to conventional systems (Mouron et al. 2012; Pelzer et al. 2012). Moreover, as IPM approach includes the use of the most effective formulations and safest application technologies, and can result in fewer pesticide applications, health risks to agricultural workers and rural communities are minimized (Brenner et al. 2003).

Farmers' attitudes towards innovation are also important when it comes to adoption of new crop protection methods. They determine whether farmers know (about new techniques), be willing (to apply), be able (have the skills), be allowed (social component for change) and dare (to experiment) to apply new techniques.

This section discusses private incentives for integrated pest management adoption, i.e. those factors likely to encourage European farmers to adopt IPM principles in the absence of mandatory regulation and specific policy instruments. Overall, there is lack of quantitative evidence on the potential of integrated pest management to increase economic sustainability relative to non-IPM strategies related to European agroecosystems. However, there are little arguments against the fact the application of IPM general principles will represent for farmers the opportunity to increase returns via saving on costs. Until now, adoption of IPM practices has allowed producers to get access to specific markets, but did not guarantee any price premium. The new legislation is not expected to have any major impact on market organization, since it only transforms a requirement imposed by retailers into one imposed by the European legislator. It will only force retailers and producers organizations to revise their certification schemes and include requirements going beyond the legal ones. Finally, the behavioural factors briefly presented can explain why, even when alternative pest control methods are more profitable than chemical control, other external incentives can be required, at least during a transition period, towards IPM adoption. We further explore and expand on policy drivers in the next section.

\section{Public policies to foster integrated pest management adoption}

Whilst pest management decisions are made at the farm level, they can be influenced or constrained by public policies. The question is whether the private incentives presented in the previous section are sufficient to lead to a rapid and wide adoption of IPM principles or whether there is room for government intervention. Through the Sustainable Use Directive, the European Union has decided to rely on regulation and has made the adoption of IPM general principles mandatory for all European farmers. In the first instance, it is interesting to understand the rationale behind policy intervention in crop protection. Secondly, we present and evaluate the usefulness of a number of potential options available within a policy "toolbox". Whilst we rely on the economic literature on the role of policy drivers in adoption of new practices in general, we always have in mind the actual context in the European Union and illustrate some of the practical challenges in the design and implementation of such policies in the current European Context.

\subsection{Why is public intervention necessary in crop protection?}

Crop protection in agriculture presents various cases of market failure (Waibel 1993). Market failures are situations where individuals' pursuit of pure self-interest leads to results that are not efficient, i.e. that deviates from the socially optimal pest control practices maximizing the net benefit to society including consumers, farmers, plant protection products producers, as well as the environment. Market failure remains one of the most influential arguments for public intervention. Having in mind the market failure framework, we illustrate here why and to what extent public policies have a role and are necessary to promote IPM adoption in Europe.

\subsubsection{Crop protection and externalities}

Whilst farmers are private entrepreneurs, taking their business decisions individually, outside agents are impacted unintentionally, both positively and negatively, by pest management practices. Externalities associated with crop protection decisions are numerous, with impacts at diverse levels: farm workers, soil and water contamination, degree of pest pressure and resistance and impact on the quality and safety of food (Sexton et al. 2007). These externalities are usually not taken into account in the market in the form of higher prices for pesticides, or lower prices for pesticide-intensive crops. Moreover, farmers usually do not take into account the costs of compensating other agents for possible environmental or health damages due to their farming practices for which they can be held liable. This implies that the signals received by farmers when they have to take decisions relative to crop protection are inefficient. Whereas farmers can have private benefits from IPM adoption in the form of increased profits or non-pecuniary advantages (as described in Section 2), many of the benefits of the adoption of IPM principles are also in terms of avoided negative externalities, benefiting society at large. Extra incentives, either through mandatory or voluntary approaches, are therefore required to make the time and financial investment associated with IPM adoption attractive and economically viable, particularly in a transition period as currently being experienced in Europe (Waterfield and Zilberman 2012). The design of policy instruments should be such that farmers integrate the social benefits from IPM adoption in their objective function when taking decisions about pest management. 


\subsubsection{Crop protection, landscape ecology and coordination failure}

Coordination failure arises when a group of farms could achieve a situation more desirable for society but fail to do so because of the absence of coordinated decisions, although each individual understands the challenges and recognises the need for action. For example, since pest populations migrate across farms and wider areas, coordinated pest control actions amongst farmers confronted with the same pest pressure is an optimal IPM approach. It allows prevention of pest population spread, damage and resistance build-up at both farm/field and landscape levels. Recent results in landscape ecology have shown that IPM activities designed at the landscape/regional scale can offer greater benefits than IPM at field level because of the positive externalities from one farm to the other (McKee 2011) (e.g. pheromones insect traps (Tscharntke et al. 2007)). However, regional IPM strategies are considered most costly to implement as they require additional societal acceptance, coordination and cooperation amongst farmers (Brewer and Goodell 2012), and different forms of incentives are necessary to encourage their development at such scales.

Given this clear role for public policies to promote IPM adoption, we present in the next section the instruments currently used in Europe and illustrate some of the practical challenges in their design in order to address these market failures.

\subsection{How can public policies encourage IPM adoption?}

Over the years, a number of instruments have been proposed to influence farmers' decisions with regard to crop protection. They can be classified in three categories: regulatory instruments, information dissemination measures and incentivebased instruments. Here, we discuss the advantages and limits of these instruments for the promotion of IPM adoption, both in the transition period of implementation of the Sustainable Use Directive and in the long run.

\subsubsection{Regulatory instruments}

With regulatory instruments, public authorities mandate and control the environmental performance to be achieved or the technologies to be used by farms. In recent years, the European Union has released several regulations and directives, ${ }^{6}$

\footnotetext{
${ }^{6}$ From the Treaty on the functioning of the European Union Article 288 : "A directive shall be binding as to the result to be achieved upon each Member States to which it is addressed but shall leave to the national authorities the choice of form and methods." It can be distinguished from regulations which are self-executing and do not require any implementing measures. Directives normally leave member states with a certain amount of leeway as to the exact rules to be adopted.
}

either targeting IPM directly or with potential indirect impacts on IPM adoption.

Different pieces of European and national legislations have been developed over recent years to regulate pesticide use. Whilst they do not target IPM adoption, they may indirectly favour the use of alternative pest control methods by constraining the use of certain active substances and plant protection products. Firstly, the criteria for the approval of active substances are regulated at the European Union level, whilst authorisations to place plant protection products on the market remains the responsibility of individual Member States (EU 2009). Secondly, the European Union also imposes Maximum Residue Levels of pesticides permitted in food products (EU 2005). Maximum Residue Levels are the upper legal levels of a concentration for pesticide residues in or on food, or feed, based on good agricultural practices and to ensure the lowest possible consumer exposure. Finally, European Union legislators have also specified requirements with which machinery for pesticide application must comply before being placed on the market and/or put into service (EU 2009).

In addition, as part of the pesticide package, the Sustainable Use of pesticides Directive 2009/128/EC explicitly mentions IPM, from where two fundamental types of provisions are distinguished: obligations imposed to all the professional users of pesticides in the European Union, and, secondly, obligations imposed at Member State level. Concerning professional users, the mandatory character of IPM is reflected in Regulation (EC) No 1107/2009 concerning the placing of plant protection products on the market (Article 55). Therein, it is stated that plant protection products shall be used properly, and proper use includes the compliance with the general principles of integrated pest management defined in annex III of the directive, which shall apply at the latest by 1 January 2014 (EU 2009). Concerning the obligations imposed at the Member State level, according to article 14 of the Sustainable Use Directive (EU 2009), Member States have to describe in their National Action Plans how they ensure that the general principles of IPM are implemented by all professional users by 1 January 2014. Furthermore, beyond the general principles of IPM, Member States shall establish appropriate incentives to encourage professional users to implement crop or sector-specific guidelines for integrated pest management on a voluntary basis. ${ }^{7}$

Amongst the practical challenges in the implementation of the Sustainable Use of Pesticides Directive, there is the fact that the introduction of two levels of responsibilities (at the

\footnotetext{
${ }^{7}$ The development and implementation of Member State National Action Plans are still on-going and it is difficult to assess, at this stage, levels of consistency/variability between Member States or expected or anticipated levels of success with respect to overall IPM adoption (this would be subject of a future analysis from a period of application and experience, unable to be addressed effectively at this stage, and as such is beyond the current scope of this review).
} 
individual level for every professional user, and at the Member State level) resulted in dilution of responsibilities and increases the need for coordination. Indeed, there is a risk that, if crop-specific guidelines are not available at the Member State level, then making adoption of general IPM principles mandatory at individual level will not have a major impact. Moreover, another challenge relies on the fact that individual Member States are responsible for the crop-specific guidelines, but international organizations already have taken on board part of this task. For example, major activities of the International Organisation for Biological Control (IOBC) include "the practical implementation of biological and integrated controls for pests and diseases of particular crops" (IOBCWPRS web). However, the guidelines available still need to be refined to be of practical use for producers, as well as updated with the latest scientific advances concerning the efficiency of different plan protection strategies and their integration.

Beyond legislation related to pesticides use, it is also important to consider the full regulatory environment on agriculture, as pest management decisions are inevitably impacted by the agricultural policy (Sexton et al. 2007). The Sustainable Use Directive is consistent with the objective of the European Common Agricultural Policy (CAP) to promote more sustainable farming practices. When the Sustainable Use Directive is finally implemented in all Member States, and the obligations directly applicable to farmers clearly identified through their respective National Action Plans, the relevant parts of the Directive should be included in the system of cross compliance (EU 2013). The exact timing will depend of the proper implementation on the ground. Under this so-called cross-compliance system, Member States impose penalties in the form of reduction or exclusion of CAP support in case of non-compliance of individual farmers.

A similar approach was retained in Switzerland, where, in 1996, Swiss citizens voted for an amendment to the federal constitution to include the principle of multi-functionality and sustainability for the Swiss agricultural sector. As a result, it was decided that farmers should enrol in a national programme on ecological production and respect the guidelines of either integrated or organic production in order to qualify for direct payments. At that time, the requirements to comply with integrated crop/livestock production were: management of crop rotation, cultivation of meadows, ground covering, closure of nutrition cycles, phosphorus and nitrogen balances, use of pesticides only if damage thresholds are reached, ecological set-asides on at least $5 \%$ of arable land, buffer strips along surface water, hedges and forest (Swiss 1996). In 2005, target objectives were achieved with $90 \%$ of the cultivated land in integrated production and $10 \%$ certified as organic. Nowadays, organic farming receives extra compensation on top of direct payments (ecological direct payment) but integrated production is not rewarded since it became the norm.
Rather, the Swiss Confederation supplements farmers' incomes with direct payments on condition that a "Proof of Ecological Performance" is made (Swiss Confederation 2013). Besides direct payments, farmers profit from joining the national programme by being able to market their produce under Swiss-wide unified labels for either integrated production (IPSuisse (Table 1)) or organic production (Bio Suisse).

Following a similar path, European Policy makers have chosen to make adoption of IPM general principles mandatory at farm-level. The penalties in case of non-commitment (defined by the Member States in accordance with Article 17 of the Sustainable Use Directive) together with the cross compliance regime act as an incentive for farmers to adopt IPM. But Member States are also required by the Article 14 of the Directive to "establish appropriate incentives to encourage professional users to implement crop or sector-specific guidelines for integrated pest management on a voluntary basis". Despite the fact that a mandatory approach has been chosen, it is recognised that there are adjustment costs to the new legal requirements. This may create the needs for incentive-based instruments, likely to compensate part of these costs. Moreover, to allow the application of general principles of IPM from all professional users, an increase in advisory services has been identified as a central resource to assist practitioners with the necessary technical and economical adjustments, inherent to IPM adoption. We develop in the next section the role of information dissemination measures and support to farmers' training.

\subsubsection{Information dissemination measures}

Persistent barriers to the adoption of new farming practices include, amongst other factors, limited availability of and access to production and market information (Atanu et al. 1994; Lohr and Salomonsson 2000; Dimara and Skuras 2003). The objectives of training and advisory systems is first to raise awareness and to stimulate farmers' interest in alternative methods of pest management (Schreinemachers and Tipraqsa 2012), then to provide farmers with the necessary tools to implement crop-specific guidelines for IPM (Braun et al. 2006). Educational programs are a useful method for approaching the complex problem of pesticide regulation, especially when there are uncertainties regarding the efficacy or environmental effects of alternative crop protection methods and when the integration of different approaches is the solution (Goodhue et al. 2010).

Information measures important for IPM adoption include free or subsidized pest management advisors, independent from, and complementary to, the advice provided by companies or commercial entities selling plant protection products (Waterfield and Zilberman 2012). Moreover, advisory services should contribute to the implementation of farmers groups in order to share the costs associated with IPM and 
to better manage spillovers at landscape-scale (e.g. through cooperatives). Demonstration farms are considered very valuable measures for both knowledge exchange between research, advisors and farmers and for the efficient dissemination of IPM methods to other farmers. Demonstration activities serve as proof of concept and are often highly appreciated within farming communities (Bailey et al. 2006).

The Sustainable Use Directive places considerable emphasis on such measures. European Union Member States have to provide professional users with information and tools for pest monitoring and decision making, as well as advisory services (Article 14). Measures for risk reduction and information about IPM are listed in the training subjects (Annex I to the Directive). In the National Action Plans recently released by Member States, training measures for farmers, advisors and pesticide distributors, as well as the establishment of advisory services and dissemination measures have a critical and central role (Table 2). Many countries already have mandatory farmer training and now include IPM issues in their existing schemes. A novel component here is that the training of advisors or trainers will become mandatory in most countries, in order to ensure that up-to-date technical information and approaches are disseminated (Dachbrodt-Saaydeh 2013).

Such IPM training activities could be organized and expanded within the framework of the CAP Farm Advisory Services (FAS) since it is foreseen that Member States should provide advice to farmers through the Farm Advisory System on the proper use of plant protection products, and in particular compliance with the general principles of integrated pest management. Advisory services offered to farmers can be free or not, face-to-face, through brochures, internet, seminars .... If the advice is not free, countries can decide to include training in the list of possible rural development measures ${ }^{8}$ and farmers applying to such measure would receive compensation for the cost of training (EU 2013). Such compensations are part of the incentive-based instruments, developed in the next sub-section.

\subsubsection{Incentive-based instruments}

Whilst European policy makers have decided to rely on mandatory approaches to reach the adoption of the general principles of IPM by all farmers, there is still some room for incentive-based instruments. Indeed, the Sustainable Use Directive recognises that incentive-based instruments can play a crucial role in the achievement of objectives relating to the sustainable use of pesticides and encourage their use, whilst

\footnotetext{
${ }^{8}$ Under the new rural development policy (Article 15 Advisory services, farm management and farm relief services), it is explicitly stated that support can be granted in order to help farmers benefit from the use of advisory services for the improvement of the economic and environmental performance as well as the climate friendliness and resilience of their farms, and to promote the training of advisors.
}

Table 2 Mandatory training for different groups according to the implementation of the sustainable use directive

\begin{tabular}{lll}
\hline Country & $\begin{array}{l}\text { Training mandatory } \\
\text { for the advisors } \\
\text { (since/from) }\end{array}$ & $\begin{array}{l}\text { Training mandatory } \\
\text { for the agricultural } \\
\text { professionals } \\
\text { (since/from) }\end{array}$ \\
\hline Bulgaria & YES & YES (2013) \\
Czech republic & YES (2004) & YES (2004) \\
Germany & YES (1987) & YES (1987) \\
Denmark & NO & YES (1993) \\
Estonia & YES (2013) & YES (2000) \\
Spain & YES (2012) & YES (2015) \\
Finland & NO & NO \\
France & NO & NO \\
Ireland & NO & NO \\
Italy & YES (2015) & YES (1995) \\
Lithuania & YES (2012) & YES (1995) \\
Latvia & YES (2004) & YES (1995) \\
Malta & NO & YES (2004) \\
Netherlands & YES (1996) & YES (1996) \\
Poland & YES (2013) & YES (1996) \\
Portugal & YES (2006) & YES (2006) \\
Romania & YES & YES \\
Slovakia & YES (2014) & YES (2010) \\
Sweden & NO & YES \\
Slovenia & YES (1998) & YES (2001) \\
United Kingdom & NO & \\
\hline & & Y
\end{tabular}

In the National Action Plans recently released by Member States, training measures for farmers, advisors and pesticide distributors, as well as the establishment of advisory services and dissemination measures have a critical and central role. The information was compiled based on the National Action Plans by S. Dachbrodt-Saaydeh 2013. The year corresponds to the year where training have/will become mandatory for the advisors or the agricultural professionals. Many countries already have mandatory farmer training and now include IPM issues in their existing schemes. A novel component here is that the training of advisors or trainers will become mandatory in most countries, in order to ensure that up to date technical information and approaches are disseminated

stressing that individual Member States are free to include them or not in their National Action Plans. More precisely, the Sustainable Use Directive explicitly refers to the establishment of incentives to encourage the implementation of cropor sector-specific guidelines. Moreover, given that adoption of general IPM principles does not necessarily mean reduction in pesticide use, incentive-based instruments can be used as a complement to influence farmers' behaviours in that direction.

Incentive-based policies usually refer to taxes and subsidies. Taxes or subsidies can be used to modify the private incentives to the adoption of different pest management methods when users fail to take into account all the externalities of their pest control practices (Rademaekers et al. 2011). The principle is rather simple and straightforward: if the action 
of one agent provides a beneficial service to society at large, then the individual may need to be compensated (subsidy) in order to provide the socially optimal level of the service. If, on the contrary, the actions cause harm to society, then the individual may need to be charged, or taxed, for those actions to maximize collective social welfare.

The times of subsidies, or reduced value added tax rate (s) for pesticides, is now passed (Schreinemachers and Tipraqsa 2012). The elimination of environmentally harmful subsidies was the first step taken to encourage the rationalization of crop protection (Withana et al. 2012). Some European countries have even taken a further step by taxing pesticide use and subsidizing adoption of alternative crop protection methods. Here, we review some of these initiatives and present their advantages and limits in promoting IPM adoption.

\subsubsection{Tax on pesticide use}

In theory, a tax on the use of a pest control treatment constrains producers to take into account all the positive and negative externalities associated with the use of the treatment. With a well-designed tax system, pesticides are used up to the point where using more pesticides will be more costly (including also environmental damages) than beneficial (Zilberman and Millock 1997). Moreover, taxes play the role of innovation stimulation, through their impact on farmers and crop protection industries' willingness to find alternative practices (EUROSTAT 2007). It is therefore a useful complement to regulation on IPM adoption. Lastly, tax revenues can cover the costs attached to their collection, and potentially be used to finance research and extension services. Nevertheless, it should be noted that an effective tax will raise limited benefits if the agents adapt their behaviours so as not to pay the tax.

Although, in theory, taxes are appealing, a number of practical challenges limit their feasibility (Zilberman and Millock 1997). A well-designed tax should take into account all the external effects of pesticide use. It therefore requires a lot of data on biological processes (Zilberman and Millock 1997), especially given that the magnitude of these external effects varies not only with the level of pesticides applied, but also with the manner, time, and space of application. According to environmental taxation theory, the tax rate should vary from farm to farm, according to the location of the farm and the application rate and technology. Such a flexible taxation scheme has never been implemented since it would be overly costly to formulate and difficult to implement and enforce (Falconer and Hodge 2001). The few European Union countries who have introduced pesticide taxes rely on a simpler approach (Baumol and Oates 1988): they have defined an objective of reduction in pesticide use and have fixed the pesticide tax such as to attain it, with limited consideration of the marginal damage function and marginal costs of reduction ${ }^{9}$ (with the exception of the recently reformed pesticide tax in Denmark). Table 3 summarized the existing pesticide taxes in Europe.

\subsubsection{Payments for IPM adoption}

Agri-environmental measures (AEM) have been implemented within the European Common Agricultural Policy with the aim to encourage farmers to protect and enhance the environment on their farmland, when the cost of doing so outweighs the benefits at farm level. Such payments provide a compensation for the costs associated to the learning phase of adoption, or the riskiness of the new practice. Subsidies also constitute a payment for the services provided by early adopters to the community: early adopters will gather experiences and information that will benefit other farmers interested in adoption.

Under the Common Agricultural Rural Development Policy, European Union Member States have to select and specify the AEM most relevant to their particular farming systems and environmental conditions. In the programming period 2007 2013, some Member States supported integrated production in general (e.g. Austria, Portugal), whilst others targeted the implementation of integrated production in specific sectors (e.g. horticulture in Brandenburg, Germany), or under measures dealing with food quality schemes (e.g. Poland). Other agri-environmental measures have aimed to decrease the adverse impact of pesticide use but did not necessarily promote IPM. For example, compensation for riparian buffer zones along streams and lakes have been offered to Danish farmers in order to protect the aquatic environment and to prevent leaching of pesticides to ground water (Christensen et al. 2011).

Agri-environment-climate payments can cover only those commitments going beyond mandatory standards. Therefore, Member States will not be permitted to support adoption of IPM general principles via AEMs after 2014. Rather, Member States willing to design AEMs targeting crop protection will have to focus on the support to sustainable agronomic practices going beyond the mandatory requirements (e.g. Integrated Crop Management (PAN Europe 2010)).

One risk of such payments is to provide incentives for the adoption of single and crop-specific practices. Rather, they should be cautiously designed to encourage the adoption of IPM as a system, at the farm or even landscape-scale. According to Ehler and Bottrel (2000), the IPM policy experience in the USA has failed because the approach was restricted to the adoption of some specific techniques, without the required integration between them. Current agri-environmental

\footnotetext{
${ }^{9}$ Marginal cost of reduction corresponds to the increase in cost when pesticide use is reduced by one unit, or $1 \%$. Marginal damage corresponds to the increase in damage due to the increase by one unit or $1 \%$ of pesticide use. In theory, both should be taken into account to design an optimal environmental tax.
} 
Table 3 Pesticide taxes in EU

Country (date of Tax rate, base and payers implementation)

Sweden (1984) Fixed amount on every kg of active ingredient (3.3 EUR per $\mathrm{kg}$ of active substance), corresponding in average to a 5-8 \% tax rate on retail price.

Tax paid by manufacturers and importers.

Denmark (1996) Since 1998, the tax rate was equal to $54 \%$ of retail price for insecticides and $33 \%$ for herbicides, growth regulators and fungicides.

The tax scheme has been revised in 2012 to take into account the load on environment and human health of each pesticide product. The products with the least desirable properties (the higher load) are now more expensive.

Tax paid by manufacturers and importers.

Norway (1998) $€$ /ha according to product toxicity class. A new tax system was implemented in 1999. It introduced differentiation according to human health and environmental criteria. The tax is areabased with a base rate of about 3.4 euros per hectare. This is then multiplied with a factor $(0.5$ to 9$)$ for one of the five tax classes, to give the tax for each plant protection product. Standard area dose ( $\mathrm{g}$ or $\mathrm{ml}$ per hectare) is used to convert tax per hectare to tax per $\mathrm{kg}$ or litres of product.

France (2000) The General Tax on Polluting Activities (TGAP) has been applied to "antiparasitic products for use on farms, and other similar products" from 2000.

But since 2008, the TGAP was replaced by a fee on diffuse agricultural pollution collected by public water agencies from pesticide distributors, according to the quantity of active substance sold by products distributors in France and the toxicity level. The rate is equal to $2 € / \mathrm{kg}$ for dangerous organic substances and $0.90 € / \mathrm{kg}$ for mineral substances (OECD 2011).

Pesticides were suppressed from the list of products benefiting from a reduced VAT rate in 2011. VAT applied is now $19.6 \%$.

Complementary measures

Outcomes and limits

The tax revenues finance activities of the pesticides programme including education and inspections of farmers.

Around $75 \%$ of tax revenues are returned to the farmers through reduced land taxes. The remainder is used to finance various actions such as farmers' education campaign, compensation to farmers for maintaining buffer zones, tighter pesticide approval procedures...

An "integrated pest management points system" is currently developed as a tool to be used by advisory services to promote the use of integrated pest management and to be able to measure the progress.

The proceeds of the tax are distributed amongst the water and waste-treatmentplant operators.

The French National Action Plan (EcoPhyto) is mainly based on an awareness and education campaign, the development of a real-time warning system against pests and the banning of a number of substances used in pesticides.
The doses per hectare have remained stable since the tax was introduced in 1984, but the tonnage of active substance has decrease by more than $60 \%$, and the aggregate risk factor has also declined by over $70 \%$.

The treatment frequency index (TFI) has been at approximately the same level as before the tax was adopted (2.5), whereas the objective was to reach 1.7.

Moreover, Danish pesticide use has increased by around $50 \%$ from 2002 to 2011.

Given that the tax rate was not differentiated according to product toxicity until recently.
The tax rate is too low and the tax revenues cover less than the sole cost of treating pesticide contaminated water for drinking.

We have summarized here the information on the existing pesticide taxes in Europe, based on the following sources: (Aubertot et al. 2005; PAN Europe 2005; Pedersen et al. 2011; Rademaekers et al. 2011; Miljøstyrelsen 2012; Nordic Association of Agricultural Scientists 2012)

schemes in Europe also tend to have this shortcoming (e.g. support to crop rotation in France and Germany, support to mechanical weeding in Belgium). Taking advantage of the ongoing reform of the European Common Agricultural Policy and the evolution of national Rural Development plans, policy instruments could be improved towards the promotion of IPM as an integrated approach, beyond the current support to disparate single techniques.

We have described here the various European regulations, information dissemination measures and incentive-based 
instruments likely to influence farmers' decisions with regard to crop protection and favour the adoption of integrated pest management. Some of them have already been implemented in some Member States, especially with the objective to reduce pesticide use. But IPM adoption by all European farmers is a different objective. IPM adoption being a dynamic and continuous process, were the different strategies part of IPM are often implemented step-by-step, a more pragmatic approach to fit with the nature of IPM is to rely on a combination of these instruments.

Concerning the tax on pesticide use, we know that price elasticity of pesticide use is very low and therefore very high tax rates are needed to achieve reduction (Falconer and Hodge 2001; Jacquet et al. 2011; Skevasa et al. 2012). Moreover, price elasticity is also likely to decrease with efforts to reduce chemical control, therefore the tax rate should increase when the quantity of pesticide reduces. Therefore, given that such tax rates are rarely politically acceptable, a pesticide tax, as a stand-alone measure, is ineffective and should be complemented by other financial incentives and extension services (Falconer and Hodge 2000). For example, taxes that differentiate according to toxicity are effective only if farmers are informed on the use of low-toxicity substitutes (Skevasa et al. 2012).$^{10}$ Moreover, it should be noted that whereas pesticide taxes are useful to encourage pesticide use reduction in a more flexible way than bans on active substances, they do not provide incentives to adopt IPM as a systematic and/or holistic approach. Efficient training on the various crop protection strategies available, and on their integration is necessary to promote crop protection strategies going beyond the reduction of pesticide use.

The effectiveness of these policies likely to foster IPM adoption will differ according to each farmer characteristic and farming system, not least crop. Whilst the approach retained in Europe consists in accepting that IPM general principles are applicable to all crops and across all Member States, farmers' reaction to policy instruments can be highly diverse. For example, since fruits producers have a very low share of their income coming from agricultural policy payments, they are more dependent on farm-gate prices they receive for their products, compare to arable farmers for example. Therefore, they may be more likely to adopt practices for which they will get a price premium, or at least new market access. Large-scale adoption of IPM, beyond the mandatory general principles, may therefore only be achieved through crop-specific and region-specific programs (Vasileiadis et al. 2011; Mouron et al. 2012).

\footnotetext{
${ }^{10}$ Pesticides are categorized in toxicity classes in the European Union's classification system, regulated by the Dangerous Substances Directive (Directive 67/548/EEC) prior to 2016, and the regulation (EC) No 1272/2008 of the European Parliament and of the Council on classification, labelling and packaging of substances and mixtures from 2016.
}

\section{Conclusion}

In this review, we have tried to decipher and understand the pertinent drivers of changes in farmers' pest management practices and their expected reaction to different policy incentives targeting IPM adoption, in a context of legislative change in the European Union. Indeed, a good understanding of the spectrum and relevance of private incentives is a first step towards the design of more efficient policies. Based on the results from the literature and considerations discussed above, we propose a framework summarizing the incentives for integrated pest management adoption (Fig. 3). It includes four main categories of drivers: first, the cost-effectiveness and impact on risk of IPM technology, the market drivers (access to market and farm-gate price for IPM products, input prices) and farmers' attitudes towards innovation, the environment and health risks correspond to the private incentives for adoption. The last box recaps the policy instruments likely to further support adoption, when private incentives are too weak, especially in a transition period, or when the market sends wrong signals in the presence of external effects of farmers' crop protection decisions.

We briefly summarize here the main results. We have reviewed the incentives linked to the cost-effectiveness of IPM technology. Whilst adoption of IPM principles can provide positive economic benefits for farmers in the form of reduced costs, large variations according to the specific IPM practice under study, the crops and local conditions, are expected. Unfortunately, experience in Europe is too limited to provide general guidance to farmers on the most technically and economically efficient IPM strategies at present. As pointed-out in the Sustainable Use of Pesticide Directive, crop-specific guidelines are still to be developed. Concerning market incentives, it is clear that products grown using IPM methods are currently rarely identified as such in the European market place. Up to now, certification schemes including IPM requirements have functioned rather as market entry requirement, or a condition for selling in specific market segments. Early adopters did not get a premium for IPM products, unless in the cases where compliance with IPM approach allowed to reach higher market segments. In this context, it is not expected that mandatory adoption of IPM principles will have a strong impact on the output markets. We have also considered the importance of non-financial incentives likely to foster IPM adoption, such as concern for reducing profit variability, as well as environmental and health risks. It is now well recognised that attitudes are clue, especially when the profitability of a new technology is not well known.

In the European context, a clear argument still remains for the role of public intervention in promoting IPM adoption. The main arguments supporting public intervention in crop protection include the fact that signals received by farmers when they have to take decisions relative to crop protection 
are inefficient, given the existence of externalities, as well as the need for coordinated action at landscape-level, in order to reach maximum benefits from IPM. Adoption of IPM general principles has been made mandatory for all farmers through European Union legislation but we have shown in this article that incentive-based and information dissemination measures are useful complementary instruments.

Incentive-based instruments impact the profitability of IPM by increasing pesticide costs through taxes and subsidizing farmers for the specific production practices whose social benefits are larger than individual private ones. Information dissemination should complement such incentive-based measures to modify farmers' attitudes towards risk (e.g. by the design or support of adequate insurance products), innovation (e.g. by the empowerment of extension services on IPM) and the environmental and health consequences of their decisions. Importantly, adoption of alternative farming technologies does not depend only on farmers, but often requires changes in the whole system. Thus, there is also a role for the State to promote recognition of IPM across the whole agri-food sector, including retailers and end-consumers. Policies for IPM promotion should search for high integration among all such instruments.

Acknowledgments The research leading to this article has received funding from the European Union Seventh Framework Programme PURE under the grant agreement $n^{\circ} 265865$. This work does not necessarily reflect the view of the European Union and in no way anticipates the Commission's future policy in this area. The authors would like to thank Silke Dachbrodt-Saaydeh, Alison Burell, Patrizia Pitton and Aymeric Berling for providing valuable inputs and comments. We would also like to thank the partners of the PURE FP7 (Innovative crop protection for sustainable agriculture, www.pure-ipm.eu) and participants of the "Future of IPM" conference (Riva del Garda, Italy 19-21 March 2013) for inspiring discussions.

\section{References}

Areté Consultants (2010) Inventory of certification schemes for agricultural products and foodstuffs marketed in the EU member states: Data aggregations. Report prepared for the European Commission DG Agriculture.http://ec.europa.eu/agriculture/quality/certification/ inventory/inventory-data-aggregations_en.pdf. Accessed 11 June 2014

Atanu S, Alan Love H et al (1994) Adoption of emerging technologies under output uncertainty. Am J Agric Econ 76:836-846. doi:10. 2307/1243745

Aubertot, J. N., J. M. Barbier, et al. (2005) Pesticides, agriculture et environnement: Réduire l'utilisation des pesticides et en limiter les impacts environnementaux. Rapport d'Expertise scientifique collective INRA et Cemagref.http://www.observatoire-pesticides.fr/ upload/bibliotheque/704624261252893935317453066156/ pesticides synthese inra_cemagref.pdf. Accessed 11 June 2014

Babcock BA, Lichtenberg E et al (1992) Impact of damage control and quality of output: estimating pest control effectiveness. Am J Agric Econ 74:165-172. doi:10.2307/1243000
Bailey AP, Garforth CJ et al (2006) Helping farmers adjust to policy reforms through demonstration farms: lessons from a project in England. J Farm Manag 12(10):613-625

Bailey A, Bertaglia M et al (2009) Integrated pest management portfolios in UK arable farming: results of a farmer survey. Pest Manag Sci 65(9):1030-1039. doi:10.1002/ps. 1790

Bale, J., J. van Lenteren, et al. (2008) Biological control and sustainable food production. Philosophical Transaction of the Royal Society Biological Science. 363(761-76) doi:10.1098/rstb.2007.2182

Baumol WJ, Oates WE (1988) The theory of environmental policy. Cambridge University Press, New York

Bazoche P, Bunte F et al (2013) Willingness to pay for pesticides' reduction in EU: nothing but organic? Eur Rev Agric Econ. doi: 10.1093/erae/jbt011

Beckmann V, Wesseler J (2003) How labour organisation may affect technology adoption: an analytical framework analysing the case of integrated pest management. Environ Dev Econ 8(3):437-450. doi:10.1017/S1355770X0300238

Beckmann, V., E. Irawan, et al. (2009) The effect of farm labor organization on IPM adoption: Empirical evidence from Thailand. ICAR Discussion Paper.http://purl.umn.edu/55767. Accessed 11 June 2014

Biguzzi C, Ginon E et al (2014) Consumers' preferences for integrated pest management: the case of tomatoes. EAAE Congress, Ljubljana, pp 26-29

Bonabana-Wabbi J, Taylor DB et al (2012) A limited dependent variable analysis of integrated pest management adoption in Uganda. J Agric Sci Technol A 2:1162-1174

Boussemart J-P, Leleu H et al (2011) Could society's willingness to reduce pesticide use be aligned with farmers' economic selfinterest? Ecol Econ 70(10):1797-1804. doi:10.1016/j.ecolecon. 2011.05.005

Boussemart, J.-P., H. Leleu, et al. (2012) Exploring cost dominance between high and low pesticide use in French crop farming systems by varying scale and output mix. Working Papers IESEG School of Management.http://my.ieseg.fr/bienvenue/DownloadDoc.asp? Fich=231112724 2012-ECO-11 Leleu.pdf. Accessed 11 June 2014

Braun, A., J. Jiggins, et al. (2006) A Global Survey and Review of Farmer Field School Experiences. International Livestock Research Institute.http://intranet.catie.ac.cr/intranet/posgrado/met $\% 20$ cual $\%$ 20inv\%20accion/mciap2010/semana\%203/documentossem310/ review\%20of\%20ffs\%20braun\%202006.pdf. Accessed 11 June 2014

Brenner, B. L., S. Markowitz, et al. (2003). "Integrated pest management in an urban community: a successful partnership for prevention." Environmental Health Perspective Retrieved 13, 111, from http:// www.ncbi.nlm.nih.gov/pmc/articles/PMC1241688/pdf/ehp0111001649.pdf.

Brewer MJ, Goodell PB (2012) Approaches and incentives to implement integrated pest management that addresses regional and environmental issues. Annu Rev Entomol 57:41-59. doi:10.1146/annurevento-120709-144748

Canali, G. (2011) The role of the "integrated production" scheme in the fruit and vegetable CMO. The common agricultural policy after the Fischler reform. A. Sorrentino, R. Henke and S. Severini. Farnham, England, Ashgate. 417-430

Carlson, G. and M. Wetzstein (1993) Pesticides and pest management. Agricultural and Environmental Resource Economics. G. Carlson, D. Zilberman and J. Miranowski. New York, Oxford University Press. 268-318.

Christensen T, Pedersen AB et al (2011) Determinants of farmers' willingness to participate in subsidy schemes for pesticide-free buffer zones: a choice experiment study. Ecol Econ 70:1558-1564. doi:10. 1016/j.ecolecon.2011.03.021

Cubie, J. (1999) Promoting Conservation Innovation in Agriculture Through Crop Insurance. United States Department of Agriculture Agricultural Outlook Forum 1999 
Cuyno LCM, Norton GW et al (2001) Economic analysis of environmental benefits of integrated pest management: a Philippine case study. Agric Econ 25(2-3):227-233. doi:10.1016/S0169-5150(01)00080-9

Dachbrodt-Saaydeh S (2013) Goals in national action plans and IPM implementation - core elements of the sustainable use Directive, Future of IPM. Riva del Garda, Italy

Dimara E, Skuras D (2003) Adoption of agricultural innovations as a twostage partial observability process. Agric Econ 28:187-196. doi:10. 1016/S0169-5150(03)00003-3

EC (2010) Communication on EU best practice guidelines for voluntary certification schemes for agricultural products and foodstuffs (2010/C 341/04).http://eur-lex.europa.eu/LexUriServ/LexUriServ. do?uri=OJ:C:2010:341:0005:0011:en:PDF

Ehler, L-E Bottrel D-G (2000) The illusion of pest management. Issues Sci Technol. 16.

ENDURE (2010) The potential role of supermarket procurement strategies as drivers of IPM. ENDURE Policy Brief.

EU (2005) Regulation (EC) No 396/2005 on maximum residue levels of pesticides in or on food and feed of plant and animal origin http:// eur-lex.europa.eu/LexUriServ/LexUriServ.do?uri= OJ:L:2005:070:0001:0016:EN:PDF

EU (2009) Directive 2009/127/EC amending Directive 2006/42/EC with regard to machinery for pesticide application.http://eur-lex.europa. e u / L e x U ri S e r v / L e x U ri S e r v. d o ? u r i = OJ:L:2009:310:0029:0033:en:PDF

EU (2009) Directive 2009/128/EC of the European Parliament and of the Council of 21 October 2009 establishing a framework for Community action to achieve the sustainable use of pesticides.http://eur-lex.europa.eu/LexUriServ/LexUriServ.do?uri= OJ:L:2009:309:0071:0086:en:PDF

EU (2009) Regulation (EC) No 1107/2009 concerning the placing of plant protection products on the market.http://eur-lex.europa.eu/ $\mathrm{L}$ e $\mathrm{x} U \mathrm{r}$ i S e r v/ L e x U r i S e r v. d o ? u r i = OJ:L:2009:309:0001:0050:EN:PDF

EU (2013) Proposal for a regulation of the European Parliament and the Council on the financing, management and monitoring of the common agricultural policy (the horizontal regulation) 2011/0288 (COD).http://ec.europa.eu/agriculture/cap-post-2013/legalproposals/com628/628 en.pdf

Europe PAN (2005) Pesticide taxes: national examples and key ingredients. Brief No 6

PAN Europe (2010) Briefing Integrated Production and Integrated Pest Management -An agro-ecological approach to pest management and action to reduce dependence on harmful pesticides by means of strong IPM programmes.

EUROSTAT (2007) The use of plant protection products in the European Union - Data 1992-2003. The use of plant protection products in the European Union - Data 1992-2003. Accessed 11 June 2014

Falconer K, Hodge I (2000) Using economic incentives for pesticide usage reductions: responsiveness to input taxation and agricultural systems. Agric Syst 63:175-194. doi:10.1016/S0308-521X(00)00007-X

Falconer K, Hodge I (2001) Pesticide taxation and multi-objective policymaking: farm modeling to evaluate profit/environment trade-offs. Ecol Econ 36:263-279. doi:10.1016/S0921-8009(00)00236-6

Feder G, Just RE et al (1985) Adoption of agricultural innovations in developing countries: a survey. Econ Dev Cult Chang 33(2):255298. doi: $10.2307 / 1153228$

Feinerman E, Herriges JA et al (1992) Crop insurance as a mechanism for reducing pesticide usage: a representative farm analysis. Appl Econ Perspect Policy 14(2):169-186. doi:10.2307/1349498

Fernandez-Cornejo, J. (1996) The Microeconomic Impact of IPM Adoption: Theory and Application. Agricultural and Resource Economics Review.149-160.

Fernandez-Cornejo J (1998) Environmental and economic consequences of technology adoption: IPM in viticulture. Agric Econ 18(2):144 155. doi:10.1016/S0169-5150(98)80003-0
Fernandez-Cornejo J, Beach BD et al (1994) The adoption of IPM techniques by vegetable growers in Florida, Michigan, and Texas. J Agric Appl Econ 26:158-172

Florax R, Travisi CM et al (2005) A meta-analysis of the willingness to pay for reductions in pesticide risk exposure. Eur Rev Agric Econ 32(4):441-467. doi:10.1093/erae/jbi025

Freier, B. and E. F. Boller (2009) Integrated Pest Management in Europe-History, Policy, Achievements and Implementation. Integrated Pest Management: Dissemination and Impact. R. Peshin and A. K. Dhawan 435-454

Goodhue R, Klonsky K et al (2010) Can an education program be a substitute for a regulatory program that bans pesticides? Evidence from a panel selection model. Am J Agric Econ 92(4):956-971. doi: 10.1093/ajae/aaq032

Hillocks RJ, Cooper JE (2012) Integrated pest management - can it contribute to sustainable food production in Europe with less reliance on conventional pesticides? Outlook Agric 41(4):237-242. doi: $10.5367 /$ oa. 2012.0107

Horowitz JK, Lichtenberg E (1993) Insurance, moral hazard, and chemical use in agriculture. Am J Agric Econ 75(4):926-935. doi:10. 2307/1243980

Hurd BH (1994) Yield response and production risk: an analysis of integrated pest management in cotton. J Agric Resour Econ 19(2): 313-326

IOBC-WPRS (web) IOBC-WPRS IP \& IPM: Crop specific Integrated Production Guidelines.http://www.iobc-wprs.org/ip_ipm/IP guidelines_crop_sprecific.html. Accessed 11 June 2014

Jacquet F, Butault J-P et al (2011) An economic analysis of the possibility of reducing pesticides in French field crops. Ecol Econ 70:16381648. doi:10.1016/j.ecolecon.2011.04.003

Kogan M (1998) Integrated pest management: historical perspectives and contemporary developments. Annu Rev Entomol 43:243-270. doi: 10.1146/annurev.ento.43.1.243

Lichtenberg E, Zimmerman R (1999) Adverse health experiences, environmental attitudes, and pesticide usage behavior of farm operators. Risk Anal 19(2):283-294. doi:10.1111/j.1539-6924.1999.tb00405.x

Lohr L, Salomonsson L (2000) Conversion subsidies for organic production: results from Sweden and lessons from the US. Agric Econ 22: 133-146. doi:10.1016/S0169-5150(99)00045-6

Loureiro ML, McCluskey JJ et al (2001) Assessing consumers preferences for organic, eco-labeled and regular apples. J Agric Resour Econ 26(2):404-416

Marette S, Messéan A et al (2012) Consumers' willingness to pay for ecofriendly apples under different labels: evidences from a lab experiment. Food Policy 37:151-161. doi:10.1016/j.foodpol.2011.12.001

Marra M, Pannell DJ et al (2003) The economics of risk, uncertainty and learning in the adoption of new agricultural technologies: where are we on the learning curve? Agric Syst 75(2-3):215-234. doi:10. 1016/S0308-521X(02)00066-5

Mauceri M, Alwang J et al (2005) Adoption of integrated pest management technologies: a case study of potato farmers in Carchi, Ecuador American agricultural economics association annual meeting. Providence, Rhode Island

McCarl, B. A. (1981) Economics of Integrated Pest Management: an interpretive review of the literature. International Plant Protection Center and Department of Agricultural and Resource Economics Oregon State University.http://ir.library.oregonstate.edu/xmlui/ bitstream/handle/1957/4894/SR\%20no.\%20636_ocr.pdf? sequence $=1$. Accessed 11 June 2014

McConnachie A, de Wit M et al (2003) Economic evaluation of the successful biological control of Azolla filiculoides in South Africa. Biol Control 28:25-32. doi:10.1016/S1049-9644(03)00056-2

McKee GJ (2011) Coordinated pest management decisions in the presence of management externalities: the case of greenhouse whitefly in California-grown strawberries. Agric Syst 104(1):94-103. doi:10. 1016/j.agsy.2010.10.005 
McNamara KT, Wetzstein ME et al (1991) Factors affecting peanut producer adoption of integrated pest management. Rev Agric Econ 13:129-139. doi:10.2307/1349563

Miljøstyrelsen (2012) The Agricultural Pesticide Load in Denmark 2007 2010. Environmental review.http://www2.mst.dk/Udgiv/ publikationer/2012/03/978-87-92779-96-0.pdf. Accessed 11 June 2014

Mitchell, P. D. (1999) The Theory and Practice of Green Insurance: Insurance to Encourage the Adoption of Corn Rootworm IPM. $\mathrm{PhD}$. Iowa State University

Mouron P, Heijne B et al (2012) Sustainability assessment of crop protection systems: sustainOS methodology and its application for apple orchards. Agric Syst 113:1-15. doi:10.1016/j.agsy.2012.07. 004

Mumford JD, Norton GA (1984) Economics of decision making in pest management. Annu Rev Entomol 29:157-174. doi:10.1146/ annurev.en.29.010184.001105

Musser, W. N., B. V. Tew, et al. (1981) An economic examination of an integrated pest management production system with a contrast between E-V and stochastic dominance analysis. Southern Journal of Agricultural Economics.119-124.

Musser WN, Wetzstein ME et al (1986) Beliefs of farmers and adoption of integrated pest management. Agric Econ Res Rev 38(1):34-44

Nordic Association of Agricultural Scientists (2012) Integrated Pest Management- National Action Plans in Nordic-Baltic countries. NJF seminar 458, Estonia.https://portal.mtt.fi/portal/page/portal/

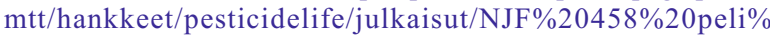
20 finaln\%20seminar.pdf. Accessed 11 June 2014

Norton GW, Mullen J (1994) Economic evaluation of integrated pest management programs: a literature review. Virginia Cooperative Extension Publication, Virginia Polytechnic Institute and State University

OECD (2011) OECD Economic survey France.

Pannell D (1991) Pests and pesticides, risk and risk aversion. Agric Econ 5:361-383. doi:10.1016/0169-5150(91)90028-J

Pedersen, A. B., H. O. Nielsen, et al. (2011) WP3 Ex-Post Case studies: The Danish Pesticide Tax. EPIWater FP7 Deliverable D3.1.http:// www.feem-project.net/epiwater/docs/d32-d6-1/CS4_Denmark.pdf. Accessed 11 June 2014

Pelzer E, Fortino G et al (2012) Assessing innovative cropping systems with DEXiPM, a qualitative multi-criteria assessment tool derived from DEXi. Ecol Indic 18:171-182. doi:10.1016/j.ecolind.2011.11. 019

Rademaekers, K., J. van der Laan, et al. (2011) The role of market-based instruments in achieving a resource efficient economy. Report prepared for the European Commission DG Environment. The role of market-based instruments in achieving a resource efficient economy. Accessed 11 June 2014

Regev U, Gotsch N et al (1997) Are fungicides, nitrogen and plant growth regulators risk-reducing? Empir Evid Swiss Wheat Prod J Agric Econ 48:167-178. doi:10.1111/j.1477-9552.1997.tb01143.x

Schreinemachers P, Tipraqsa P (2012) Agricultural pesticides and land use intensification in high, middle and low income countries. Food Policy 37(6):616-626. doi:10.1016/j.foodpol.2012.06. 003

Sexton S, Lei Z et al (2007) The economics of pesticides and pest control. Int Rev Environ Resour Econ 1:271-326. doi:10.1561/101. 00000007

Sharma A, Bailey A et al (2009) Technology adoption and pest control strategies among UK cereal farmers: evidence from parametric and nonparametric count data models. International Association of Agricultural Economists Conference, Beijing, China
Singerman, A., C. E. Hart, et al. (2011) Price Analysis, Risk Assessment, and Insurance for Organic Crops. CARD Policy Brief 11-PB 6. Iowna State University.

Skevasa T, Stefanoua SE et al (2012) Can economic incentives encourage actual reductions in pesticide use and environmental spillovers? Agric Econ 43:267-276. doi:10.1111/j.1574-0862.2012.00581.x

Stern VM, Smith RF et al (1959) The integration of chemical and biological control of the spotted alfalfa aphid. Hilgardia 29(2):81101

Swinton SM, Day E (2003) Economics in the design, assessment, adoption, and policy analysis of integrated pest management. integrated pest management: current and future strategies. K. Barker Counc Agric Sci Technol Ames Task Force Rep 140:196-206

Swiss Confederation (1996) Federal Ordinance on Ecological Direct Payments (Ökobeitragsverordnung (OeBV), January 24th, 1996.

Swiss Confederation (2013) Federal Ordinance on Direct Payments (Direktzahlungsverordnung, DZV), 23 October 2013.

Torjusen, H., L. Sangstad, et al. (2004) European Consumers' Conceptions of Organic Food: A Review of Available Research. European Commission Quality of Life and Management of Living Resources.http://www.organichaccp.org/haccp_rapport.pdf. Accessed 11 June 2014

Tscharntke T, Bommarco R et al (2007) Conservation biological control and enemy diversity on a landscape scale. Biol Control 43(3):294 309. doi:10.1016/j.biocontrol.2007.08.006

USDA (2013) Federal Crop Insurance - Organic Crops Audit Report 05601-0006-KC.R. M. Agency.http://www.usda.gov/oig/webdocs/ 05601-0006-KC.pdf. Accessed 11 June 2014

Vasileiadis VP, Sattin M et al (2011) Crop protection in European maizebased cropping systems: current practices and recommendations for innovative integrated pest management. Agric Syst 104(7):533540. doi:10.1016/j.agsy.2011.04.002

Waibel, H. (1993) Government intervention in crop protection in developing countries. Crop Protection and Sustainable Agriculture. D. J. Chadwick and J. Marsh. Baffins Lane, Chichester, Wiley

Waterfield G, Zilberman D (2012) Pest management in food systems: an economic perspective. Annu Rev Environ Resour 37:223-245. doi: 10.1146/annurev-environ-040911-105628

Withana, S., P. Brink, et al. (2012) Study supporting the phasing out of environmentally harmful subsidies. Report prepared for the European Commission DG Environment. Institute for European Environmental Policy.http://ec.europa.eu/environment/enveco/ taxation/pdf/report_phasing_out_env_harmful_subsidies.pdf. Accessed 11 June 2014

Yong-gong, L. and Q. Guo-jun (2001) Socioeconomic Study on Farmers' Adoption of Integrated Pest Management (IPM) Strategies in Brassica Vegetable Crops in China. working paper Australian Centre for International Agricultural Research.http://aciar.gov.au/ files/node/2139/iap_wp40.pdf. Accessed 11 June 2014

Yue C, Alfnes F et al (2009) Discounting spotted apples: investigating consumers' willingness to accept cosmetic damage in an organic product. J Agric Appl Econ 41(1):29-46

Zepeda JF, Barreto-Triana N et al (2006) An exploration of the potential benefits of integrated pest management systems and the use of insect resistant potatoes to control the Guatemalan tuber moth (Tecia solanivora Povolny) in Ventaquemada, Colombia. International Food Policy Research Institute, Washington, DC

Zilberman D, Millock K (1997a) Financial incentives and pesticide use. Food Policy 22(2):133-144. doi:10.1016/S0306-9192(97)00004-3

Zilberman D, Millock K (1997b) Pesticide use and regulation: making economic sense out of an externality and regulation nightmare. $\mathrm{J}$ Agric Resour Econ 22(2):321-332 